\title{
異なる強度を持つ壁土を用いた土壁耐力の推定 RESISTANT FORCE CHARACTERISTIC ESTIMATION OF WOODEN FRAMES WITH MUD PLASTERED WALLS USING MUD PLASTERS OF DIFFERENT STRENGTH
}

\author{
山田耕司*, 中治弘行**, 鈴木祥之*** \\ Koji YAMADA, Hiroyuki NAKAJI and Yoshiyuki SUZUKI
}

\begin{abstract}
In this paper, the loading tests of wooden frames with mad plaster wall and their numerical analysis are reported. Three mud plaster are made of 3 different blend of clay, sand, and straw. Results are as follows: 1) if there is no separation phenomenon of mud plaster from a lath, the horizontal resistant force characteristics of wooden frames with mud plaster wall are close to calculated by proposed method. 2) The hypothesis of mud plaster separation phenomenon represents that the tensile strength of mud plaster gives the separation horizontal load of the wooden frames with mud plaster.
\end{abstract}

Keywords : Traditional Wooden House, Mud Plaster Wall, Numerical Analysis, Horizontal Resistant Force Characteristic, Separation Phenomenon 伝統木造住宅，土塗り壁，数值解析，水平耐力特性，剥離現象

\section{1. 序}

伝統木造住宅の耐力機構に関する研究は，実大試験体による実験 的研究が多い。これは，コンクリート構造や鉄骨構造と比較して試 験体の制作費が安いこと, 最大耐力が小さく大きな実験装置を必要 としないためである。また，実大実験が多く実施されるもう一つの 要因は, 伝統木造住宅の材料および構法のモデル化が複雑であるこ とが挙げられる. 伝統木造住宅の主要な耐震要素の土塗り壁 (以下, 土壁）を例としても，実大実験に基づく研究が多くなされているが， 荷重-変位曲線を数值解析によって適切に評価した計算事例は少ない 例えば，村上ら ${ }^{122}$ は，半間幅（以後，1P：910mm）の土壁の実験を 行い，壁土がせん断破壊しない場合では，土壁の要素試験体から得 られる隅角部圧縮力と貫のこじりの物性によって, 試験体の耐力特 性が予測可能であるとしている。また，壁土のせん断破壊が先行し や寸い 1 間幅（以後, $2 \mathrm{P}: 1820 \mathrm{~mm}$ ）の土壁に関寸る代表的な研究と しては，村上ら ${ }^{3)}$ ，中尾ら ${ }^{4)}$ の実験的研究がある，村上らは要素試験 結果に基づき，初期剛性，最大耐力の推測式を提案している．中尾 らも材料実験結果に基づくせん断抵抗力の推測を行っているが，こ れらは荷重-変位曲線全体を適切に計算するには至っていない. また,

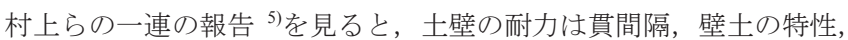
貫伏せの有無・種類，の影響を受けるとされており，土壁を含む架 構の耐力特性には未解明な部分が多いと言える.
著者らは, 動的・静的実験によって伝統木造住宅の耐震性能を再 検討 ${ }^{677}$ 寸する一方, 数值解析を含めた理論的アプローチから, 土壁の 耐力特性の要因を説明することを検討してきた. 既報 ${ }^{8)}$ では, 数值解 析から, 壁土の脆性・塑性, 架構と土壁が一体構造でないことによ る接触・分離・応力集中を考慮できる土壁解析手法を開発し，1P 土 壁と $2 \mathrm{P}$ 小壁の実験結果を模擬できることまでを示した．また，文献 9)では，土塗り小壁付き木造軸組の耐力性状を文献 10) と比較検討し た.

本報は，既報を補完するために行った壁土耐力の異なる土壁に対 する数值解析による追試を報告するとともに, 実験で観察された土 壁の小舞からの剥離現象を考察している.

\section{2. 方法 \\ 2.1 壁土の調合法}

本報では，強度の異なる土壁を作成寸るため，粘土，砂の配合を 変え強度の異なる壁土を練り合わせた。壁土試験体は，既報 ${ }^{11)}$ に基 づき作成した。 土壁に使用寸る土（以下, 壁土）は, 愛知県で得ら れた粘土 $\left(1.28 \mathrm{~g} / \mathrm{cm}^{3}\right)$, 砂 $\left(1.62 \mathrm{~g} / \mathrm{cm}^{3}\right)$, スサ $\left(0.051 \mathrm{~g} / \mathrm{cm}^{3}\right)$ とする. 材料 を写真 1 に示す.材料試験体は, 直径 $50 \mathrm{~mm}$ 高さ $100 \mathrm{~mm}$ の円柱とし, 型枠は吸水性の良いM画紙を用いた。試験体作成手順を以下に示寸.

a) 乾燥した壁土を試験体 1 本に対し $400 \mathrm{~g}$ 量り採り粉末状になる

\footnotetext{
* 豊田工業高等専門学校建築学科 准教授・博士 (工学)

**鳥取環境大学環境デザイン学科准教授・博士 (工学)

*** 立命館大学立命館グローバル・イノベーション研究機構 教授·工博
}

Assoc. Prof., Dept. of Architecture, Toyota National College of Technology, Dr. Eng. Assoc. Prof., Dept. of Environmental Design and Architecture, Tottori University of Environmental Studies, Dr. Eng.

Prof., Ritsumeikan-Global Innovation Research Organization, Ritsumeikan University, Dr. Eng. 
まで棒等で突く.

b) 壁土質量比で適量の水を混ぜ練り合わす（乾燥工程では，こ の時加えられた水に相当する水分を除去する）.

c) M画紙で作成した型枠に泥状の壁土を型枠の 3 分の 1 ずつ詰 め, 棒で 20 回付く.

d) 乾燥工程 : 定温乾燥機（I 社製 BL-115S）を用いて乾燥する. 圧縮試験前には, 試験体の上下面を削り平らにした。圧縮試験は, $\mathrm{S}$ 社製 DTB-100を用いた。

粘土・砂の配合比は，質量比で粘土：砂=1: 1, 1:2, $1: 3$ とし た。スサは，粘土・砂混合質量の $1 \%$ を基本とし，適宜変更した。圧 縮試験（5 体）および割裂試験（3 体）の試験状況を写真 2 に，結果 を図 1 に示す。圧縮強度は，0.4 $1.0 \mathrm{~N} / \mathrm{mm}^{2}$ 程度となり，割裂引張強 度 (図中の : 最初に応力度が劣化した点（割裂した応力度と判断し た））は，0.13〜0.16 N/mm²程度となった。また。今回の実験では， 圧縮強度と引張強度に正の相関は無いといえる。

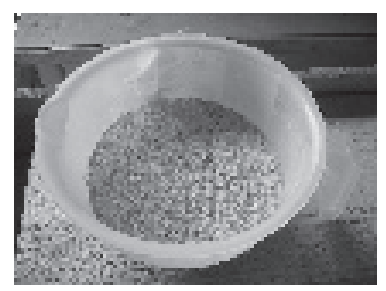

a) 士

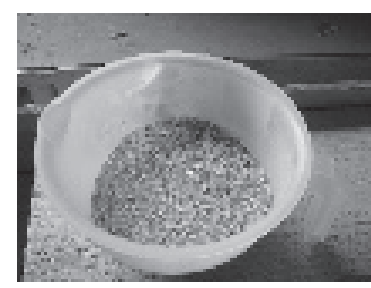

b) 砂

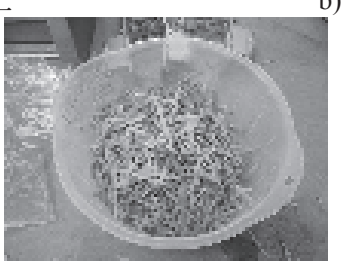

c) スサ

写真 1 材料

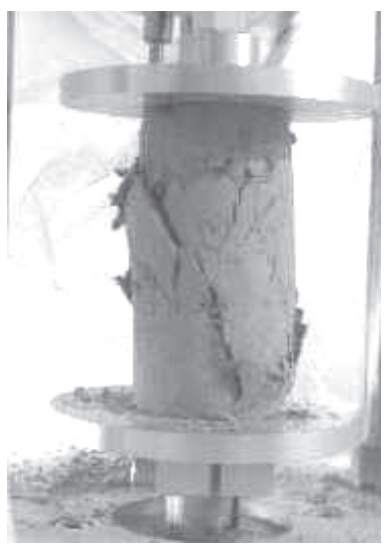

圧縮試験

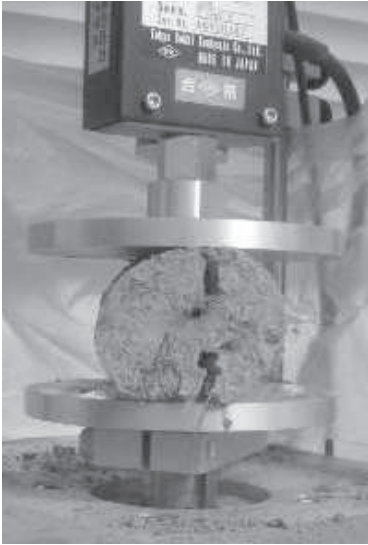

割裂試験
写真 2 圧縮試験，割裂試験

以上の結果を踏まえ，粘土 : 砂 $=1: 1$ の壁土を荒壁（強），粘土 : 砂 $=1 ： 2$ の壁土を荒壁（中），粘土：砂=1:3の壁土を荒壁（弱） として，壁試験体を作成した。なお，施工性の観点から，粘土・砂・
スサの配合は，施工者の判断で多少の変更があった。図 2 に実際に 使用した壁土の圧縮強度試験結果とそのモデル化された骨格曲線を 示す.
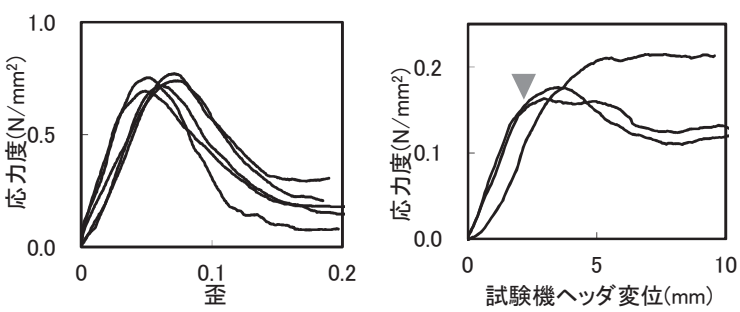

b) 土：砂：スサ $=1: 1: 1.5 \%$
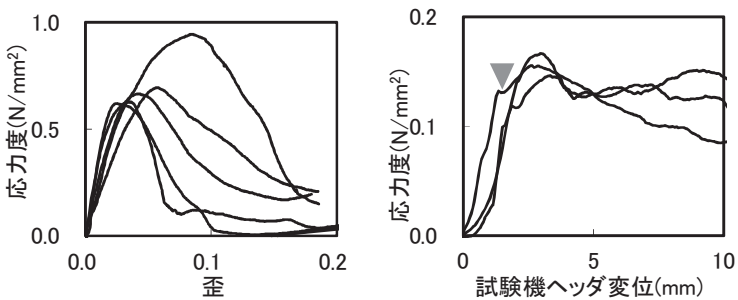

c) 土：砂：スサ=1:2:1\%
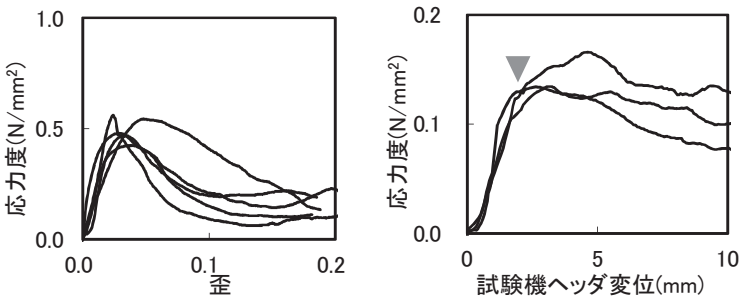

d) 土：砂 : スサ $=1: 3: 1 \%$

圧縮試験

割裂試験

図 1 材料試験結果

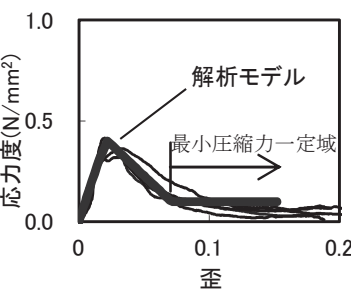

a) 荒壁（弱）

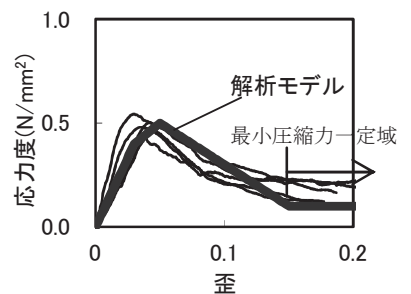

b) 荒壁 (中)

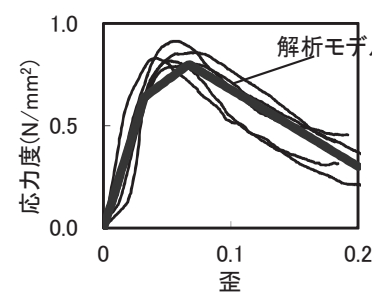

c）荒壁（強）

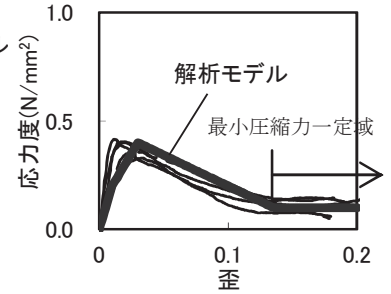

d) 中塗り
図 2 材料試験 


\section{2 壁試験体}

実験では, 図 3 に示す長さ $910 \mathrm{~mm}$ および $1820 \mathrm{~mm}$ の試験体を作成し た. 以後, 各々を $1 \mathrm{P}$ 試験体, $2 \mathrm{P}$ 試験体と称する. 試験体は, 柱・梁・ 土台はスギ 120 角とし，仕口は長ホゾ(断面 $40 * 110 \mathrm{~mm}$ ) 込み栓（12mm 角）とした. 材の含水率は, 10〜25\%であった. 貫 $(15 * 120 \mathrm{~mm})$ は 3 段, 柱との接合は，落とし鎌とし楔で留めている，土壁は，両面中塗り （（中塗り） $20 \mathrm{~mm}+$ (荒壁） $40 \mathrm{~mm}+$ (中塗り） $15 \mathrm{~mm}$ ）とし，ワラ縄で 小舞竹を編んだ．なお，柱引き抜け防止のため，ホールダウン金物 を用いている，載荷スケジュールは，1/400，1/300，1/200，1/150， $1 / 100,1 / 60 \mathrm{rad}$ を 3 回ずつ正負交番載荷し, その後, $1 / 40,1 / 30,1 / 25$, 1/15 rad を正側に片側に 1 回の繰り返し載荷を行った.

\section{3 数值解析}

数值解析は, 文献 9)で示した解析モデルを用いている. この解析 モデルでは，土壁の圧壊，貫の土壁へのめりこみ，貫・差し鴨居・ 柱頭・柱脚の回転抵抗を考慮している，そのため，解析モデルは， 土壁要素, フレーム要素, フレーム弾塑性バネ（仕口部, 貫の曲げ 抵抗をモデル化），壁土ーフレーム間の接触要素から構成される.

フレーム要素 (木質架構) は, 弾性の線材要素とし, ヤング係数 はスギを参考として $\mathrm{E}=0.7 \times 10^{4} \mathrm{~N} / \mathrm{mm}^{2}$ （せん断弾性係数 $\mathrm{G}=2.9 \times 10^{3}$ $\left.\mathrm{N} / \mathrm{mm}^{2}\right)$ とした.

仕口および貫端部に弾塑性バネを設けた。図 4 に軸力および曲げ モーメントに対する仮定した非線形履歴モデルを示す．仕口部は, 長ホゾ断面の降伏曲げモーメントで，完全弾塑性の骨格曲線を持つ スリップ型復元力特性とした。貫端部は，三角形めりこみをすると 仮定して，回転剛性，降伏モーメントを設定した。仕口部では回転

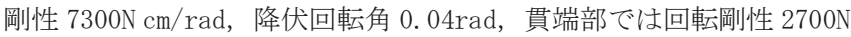
$\mathrm{cm} / \mathrm{rad}$, 降伏回転角 $0.01 \mathrm{rad}$, を与えている. なお, せん断力に対し ては，線形を仮定している。

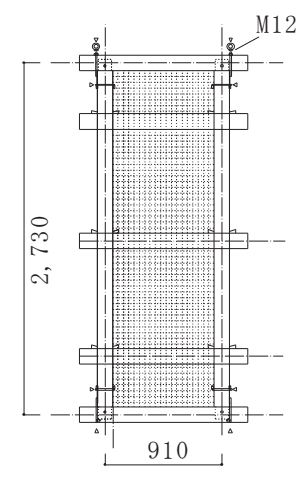

a) $1 \mathrm{P}$ 試験体

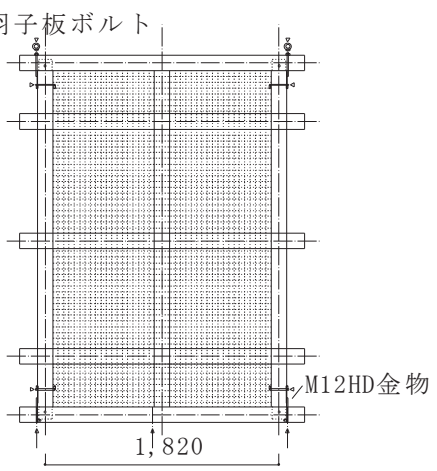

b） $2 \mathrm{P}$ 試験体
図 3 試験体概略

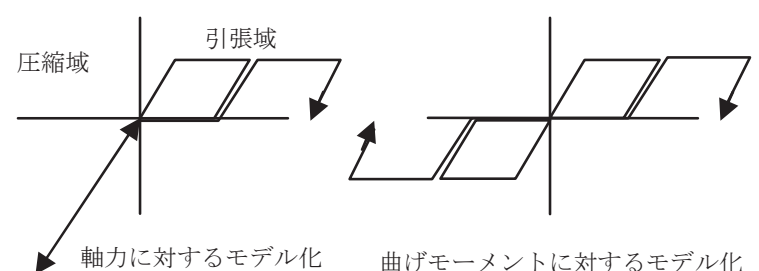

図 4 弾塑性バネモデル
土壁要素は矩形要素とした。考え方は, RC 壁要素の分散ひび割れ モデルを参考とした，参照点は, 要素中央と, ひび割れを含む弾塑 性を考慮する評価軸を, 15 度毎の 12 本設定した. 計算プロセス中は, 各評価軸方向の歪, 応力をステップ毎に再計算し, 履歴を保持する. 要素の応力の代表値は, 12 本の評価軸のうち, 要素の主歪方向に最 も近い評価軸の剛性・主応力を用いている.この場合の主軸方向の せん断応力は零としている. その後, この主歪方向の剛性・応力を 座標変換, 要素内で積分し, 剛性・節点反力を計算する, 各評価軸 は, 図 5 のように, 引張り側では, Bilinear 型とし, 第 2 勾配は負 剛性としている. 最大変位が第 2 勾配に入っている場合は, 最大点 指向型の特性とする. 圧縮側は, スリップ特性を持つTri-linear と した上で，圧縮域負剛性後に最小圧縮力一定域を設けた（図 2,6 参 照）。なお，土壁の自重は文献 5) を参考に $1.4 \mathrm{~g} / \mathrm{cm}^{3}$ とした（接触要 素で発生する摩擦力を計算する際に使用）。また, 今回の計算では, 土壁を $22.5 \mathrm{~cm}$ 角程度で等分して，モデルを作成している.

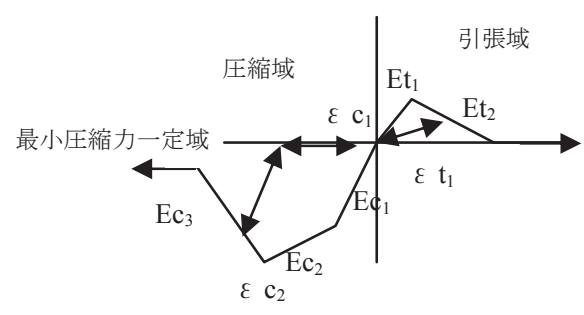

軸力に対するモデル化

図 5 土壁要素モデル

壁土ーフレーム間の接触要素は要素幅 $1 \mathrm{~cm}$ を想定した図 6 に示すよ うな矩形要素（実質は，接触対応節点間を結ぶ 2 本の非線形バネ) であり，フレーム要素直交方向力と摩擦力を伝達する. 接触対応節 点間のフレーム要素直行方向距離の増減に比例した応力伝達を仮定 している.引張域ヤング係数 $\mathrm{E}=0.0 \mathrm{~N} / \mathrm{mm}^{2}$, 圧縮ヤング係数 $39.2 \mathrm{~N} / \mathrm{mm}^{2}$ とし, 要素厚 $(\mathrm{t}) を 8 \mathrm{~cm}$ としている。各バネの剛性 $(\mathrm{K})$ は, 次式で算 出した.

$\mathrm{K}=\mathrm{E} \mathrm{t} \mathrm{L} / 2 \quad \mathrm{~L}:$ フレーム要素長

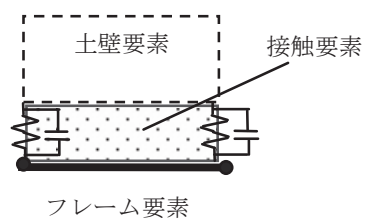

図 6

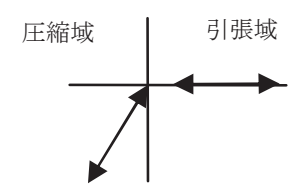

軸力に対するモデル化
6 接触要素モデル

\section{3. 実験結果と計算結果 \\ 3.1 実験結果}

試験体の繰り返し載荷結果, および, その実験結果の抱絡線と数 值解析による一方向加力結果を図 7, 9 に示す。なお, 実験の際，2P 試験体の「荒壁（中）」，「荒壁（強）」では，写真 3，4のよう 

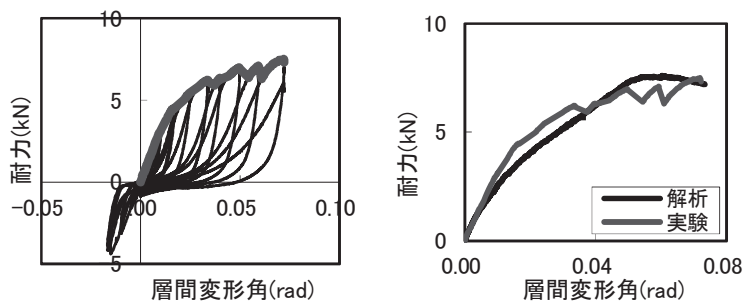

a) 荒壁（弱）
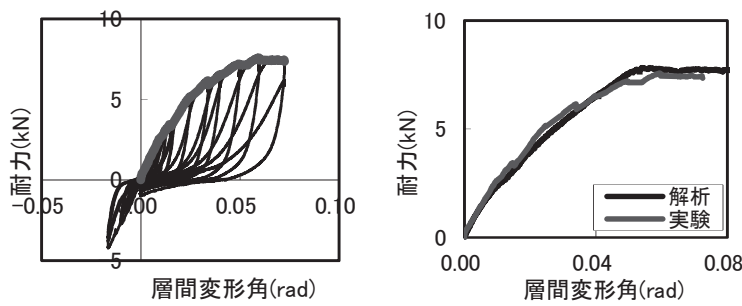

b) 荒壁（中）
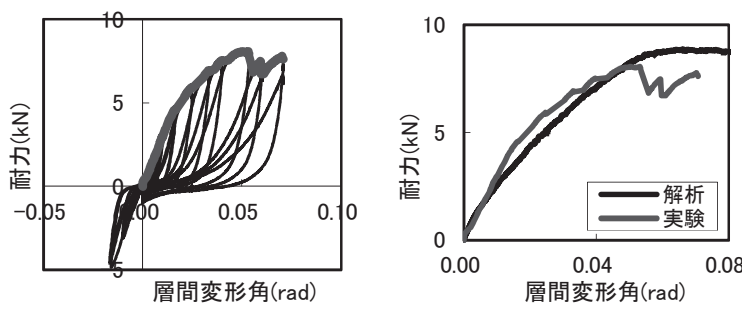

c) 荒壁 (強)

図 $71 \mathrm{P}$ 壁体の繰り返し加力試験結果
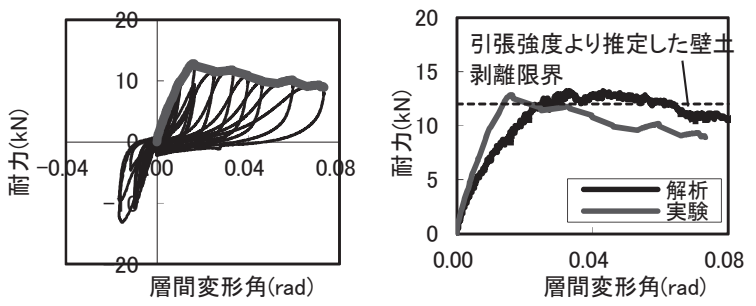

a) 荒壁 (弱)
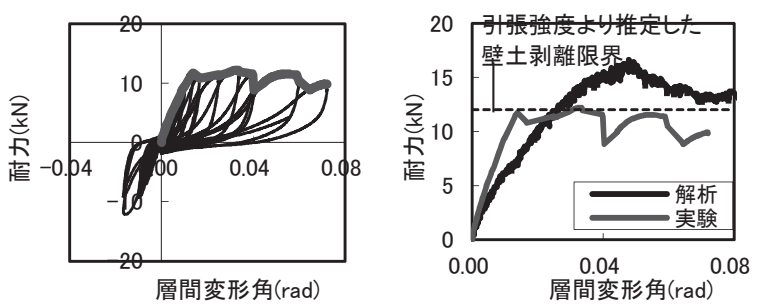

b) 荒壁（中）
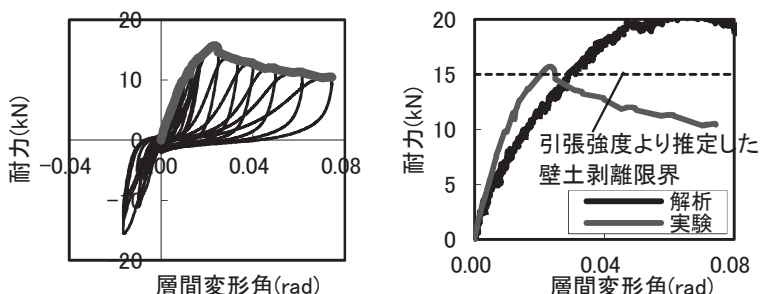

c) 荒壁 (強)

図 8 2P 壁体の繰り返し加力試験結果
に壁土の剥離が発生した。この壁土の剥離は, 図の荷重変形関係か らも読み取れるように「荒壁（中）」では，1/70 rad「荒壁（強）」 では $1 / 40 \mathrm{rad}$ で発生した。

$1 \mathrm{P}$ 試験体では，実験で得られた耐力は変形と共に耐力が増加する 傾向が得られた。 また, 数值解析は, 実験結果をほぼトレースして いる。一方, $2 \mathrm{P}$ 試験体では, 実験による荷重変形曲線に負勾配が見 られた。また，数值解析は，「荒壁（弱）」の実験結果をトレース しているものの，「荒壁（中）」，「荒壁（強）」では，壁土の剥 離以後はトレースできていない.一方, $2 \mathrm{P}$ の解析結果は $0.01 \sim 0.02 \mathrm{rad}$ 付近で下に外れている.この理由として, 貫のめり込みに関する復 元力特性は $0.01 \mathrm{rad}$ で降伏するように設定しているため, 2P の解析結 果において $0.01 \sim 0.02 \mathrm{rad}$ 付近で解析結果の耐力低下が発生している ためと考えられる.
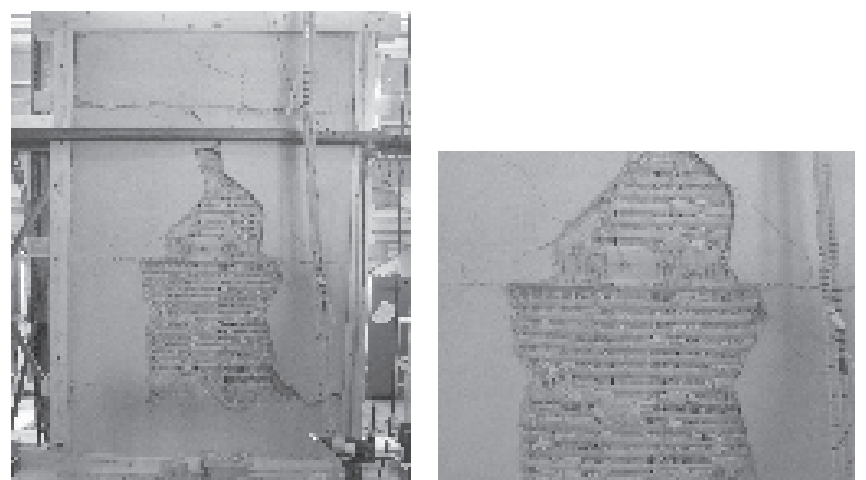

写真 3 壁土の剥離（2P 試験体荒壁（中））
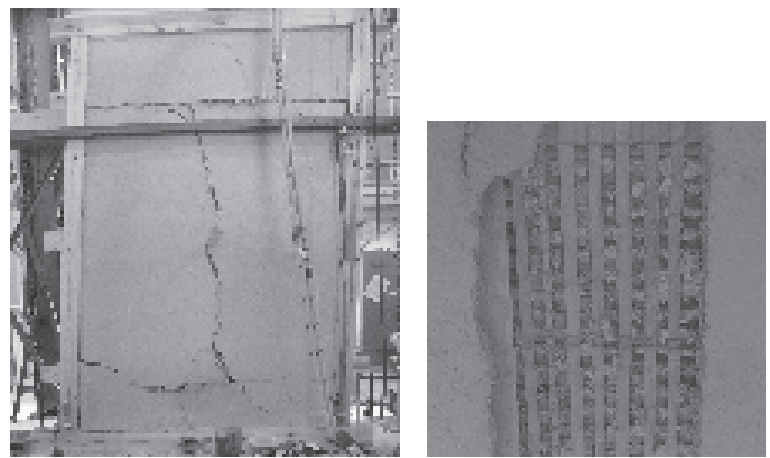

写真 4 壁土の剥離（2P 試験体・荒壁（強））

\section{2 壁土剥離耐力の推定}

前節では, $2 \mathrm{P}$ 試験体の加力中に壁土の剥離が発生し, 壁水平耐力 が低下した。 そこで本節では, 壁土剥離耐力の推定に関する次の仮 説を立てる.

$<$ 仮説 $>$

繰り返し載荷により，土壁表面にせん断亀裂が既に発生し た状態（写真 5) で，図 9 のように厚さ方向に角度 $\theta$ の亀裂進 入角が存在する.この際，壁土は小舞を通して小舞反対側の 壁土と接合されるため，剥離していない，壁面内に作用する 面内力は，面内圧縮力として伝達可能と考える。しかし，亀 裂の存在により，面内圧縮力が変換され，土壁厚さ方向に引 張力が発生し，結果として小舞表裹の土壁が剥離する。 
なお本報では, 亀裂部に生じる厚さ方向引張力は, 亀裂部 近辺に発生する面内圧縮力と亀裂進入角から計算し, 亀裂部 で生じる厚さ方向引張力と小舞間の壁土（荒壁土）の引張耐 力とを比較する.

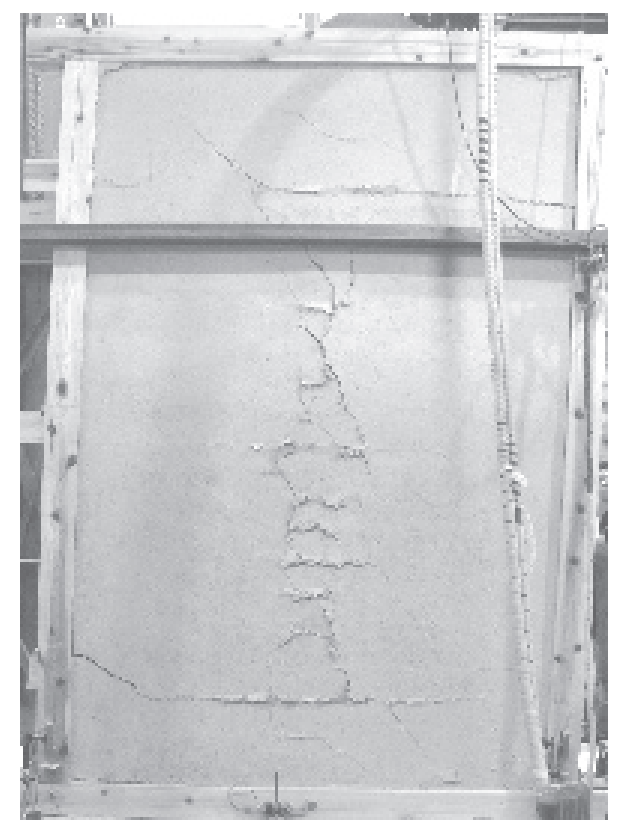

写真 5 壁土剥離仮説の対象とするせん断亀裂の例（2P 試験体）

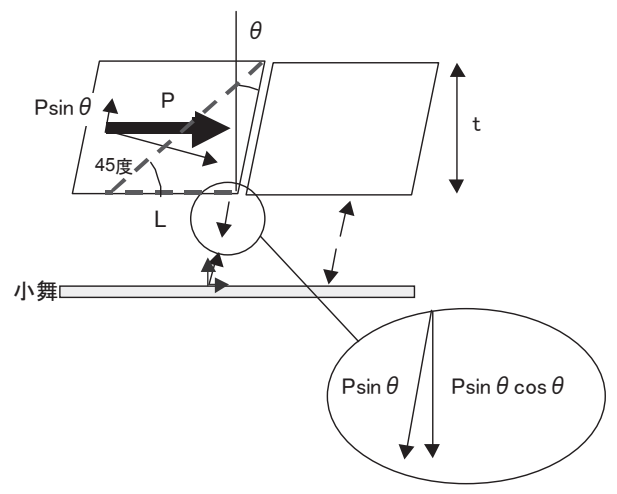

図 9 壁土剥離の仮説モデル

(小舞と小舞に取り付く壁土との応力伝達仮説)

先ず，2P 土壁中央部に発生したせん断亀裂近傍に作用する圧縮力 $\mathrm{P}$ を計算する. 今, 土壁全体に $\mathrm{Q}$ なるせん断力が作用すると, 最大 せん断応力度 $\tau$ は, $\mathrm{A}$ を土壁断面積 (土壁厚 $\times$ 土壁長) として

$$
\tau=1.5 \mathrm{Q} / \mathrm{A}
$$

と計算される．単純せん断状態では，主応力度=せん断応力度である から， $2 \mathrm{P}$ 土壁中央部の圧縮力 $\mathrm{P}$ は， $2 \mathrm{P}$ 土壁中央部のせん断応力度に 壁厚 $(\mathrm{t})$ を乗じることにより計算できる.

$\mathrm{P}=\tau \mathrm{t}=1.5 \mathrm{Qt} / \mathrm{A}$

次に, 図 9 のように土壁断面に角度 $\theta$ で亀裂の入った土壁を考え る。この土壁に左から圧縮力 $\mathrm{P}\left(=\sigma_{\mathrm{c}} \mathrm{t}\right)$ なる力が作用し, 亀裂部に摩 擦が作用しないと仮定すると，土壁が移動しない為には，P $\sin \theta$ の 抵抗力が必要である。この $\mathrm{P} \sin \theta$ の抵抗力は，小舞とその間の荒土 に伝えられ，荒壁土には，P $\sin \theta \cos \theta$ の引張力が作用する。 この
$\mathrm{P} \sin \theta \cos \theta$ が土壁断面厚 $(\mathrm{t})$ と同等の範囲 $(\mathrm{L}=\mathrm{t})$ に再配分されると 仮定すれば，壁土を剥離させようとする引張応力度 $\left(\sigma_{t}\right)$ は,

$$
\sigma_{\mathrm{t}}=\sigma_{\mathrm{c}} \sin \theta \cos \theta
$$

となる.しかし，荒壁内には小舞が配置され，引張応力を負担する 荒壁の面積が減少している. 今, $900 \mathrm{~mm}$ 角の土壁内に格子状に小舞が 配置されているとする，この時，荒壁の土が小舞を貫通する面積の 比 (空隙率: v) は, 表 1 の值となる. ゆえに先の引張応力度 （o $\mathrm{t}$ )を空隙率 $(\mathrm{v})$ で除寸必要がある。結果として引張応力度は, $\left(\sigma_{\mathrm{t}}\right)$ $\sigma_{\mathrm{t}}=\sigma_{\mathrm{c}} \sin \theta \cos \theta / \mathrm{v}=1.5 \mathrm{Q} \sin \theta \cos \theta /(\mathrm{A} \mathrm{v})$ となる. ここで, 小舞の空隙率を 0.5 と仮定すると, 必要引張強度 と圧縮応力度の比は, 土壁断面角度 $\theta$ をパラメータに表 2 となる.

表 2 より, 亀裂進入角 $\theta=45^{\circ}$ （必要引張耐力/圧縮力 $=1.0$ ） と仮 定した場合には, 必要引張応力度は圧縮応力度 (主応力度=最大せ 儿断応力度）と同值となる. ゆえに必要引張応力度は, $Q=9.5 \mathrm{kN}$ の場 合 $0.10 \mathrm{~N} / \mathrm{mm}^{2}, \mathrm{Q}=12 \mathrm{kN}$ の場合 $0.13 \mathrm{~N} / \mathrm{mm}^{2}, \mathrm{Q}=15 \mathrm{kN}$ の場合 $0.16 \mathrm{~N} / \mathrm{mm}^{2}$, となる. 図 8 中の点線は, 図 2 の割裂引張強度 (荒壁(強) で $0.16 \mathrm{~N} / \mathrm{mm}^{2}$, その他で $0.13 \mathrm{~N} / \mathrm{mm}^{2}$ ) から推定した壁土剥離時の土壁水平耐力とな る. 図より，荒壁（中）の場合はほぼ妥当な結果を示し，荒壁（弱） の場合は壁土剥離の可能性があったことが分かる.

表 1 小舞本数と空隙率

\begin{tabular}{|c|c|c|c|}
\hline 壁幅 $(\mathrm{mm})$ & 小舞幅 $(\mathrm{mm})$ & 小舞本数 $($ 本 $)$ & 空隙率 \\
\hline 900 & 15 & 13 & 0.61 \\
\hline 900 & 15 & 17 & 0.51 \\
\hline
\end{tabular}

表 2 必要引張耐力と圧縮力の比(空隙率 $\mathrm{v}=0.5$ )

\begin{tabular}{|c|c|}
\hline $\begin{array}{c}\text { 亀裂進入角 } \\
\theta \text { (度) }\end{array}$ & $\begin{array}{c}\text { 必要引張強度/圧縮応力度 } \\
=\text { 空隙率 } /(\sin \theta \cos \theta)\end{array}$ \\
\hline 10 & 0.34 \\
\hline 20 & 0.64 \\
\hline 30 & 0.87 \\
\hline 45 & 1.00 \\
\hline
\end{tabular}

以上の仮説を準用して, 壁土の最大圧縮強度から推測される壁土 の必要引張強度を計算する. 先ず, 岡本ら ${ }^{13)}$ の提唱した耐荷機構モ デルより土壁の最大水平耐力を計算した後, 土壁の水平耐力から先 の手順により荒壁土の必要引張強度を計算する。

本報では，岡本ら ${ }^{13)}$ の提唱した耐荷機構モデルの Y 方向のみ（図 10 : 貫の壁土一のめりこみ, 壁土の隅各部での圧壊のみ) を考慮し て土壁の最大水平耐力を算出寸る. この際, 土壁に作用する応力度 を三角形分布, その最大応力度を $\sigma_{\text {max }}$ と仮定する. 具体的には,

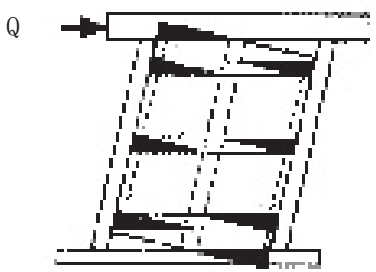

図 10 岡本ら ${ }^{13)}$ の提唱した土壁の耐荷機構モデル（Y 方向） 


$$
\begin{aligned}
& \mathrm{M}_{\mathrm{C}}=\sigma_{\max } \mathrm{t}_{\mathrm{m}} \mathrm{L}^{2} \\
& \mathrm{M}_{\mathrm{N}}=\sigma_{\max } \mathrm{t}_{\mathrm{N}} \mathrm{L}^{2} \mathrm{~N}_{\mathrm{N}} \\
& \text { ここで, } \\
& \mathrm{M}_{\mathrm{C}}: \text { 壁土の隅各部での圧壊による曲げモーメント抵抗 } \\
& \mathrm{M}_{\mathrm{N}}: \text { 貫の壁土へのめりこみによる曲げモーメント抵抗 } \\
& \mathrm{t}_{\mathrm{m}}: \text { 土壁厚 } \\
& \mathrm{L}: \text { 壁長 } \\
& \mathrm{t}_{\mathrm{N}}: \text { 貫幅 } \\
& \mathrm{N}_{\mathrm{N}}: \text { 貫段数 }
\end{aligned}
$$

で計算する。また， $2 \mathrm{P}$ 試験体における壁土剥離を防止する壁土必要 引張強度は, 空隙率 $\mathrm{v}=0.5$, 亀裂侵入角 $\theta=45^{\circ}$ （必要引張強度/圧縮 強度=1.0）として計算する。

結果として，土壁に作用するせん断力およびせん断力から計算さ れる必要引張強度は, 表 3 のようになる。本表では, 壁土圧縮強度 の 30\%程度の壁土引張強度が望まれることになる. しかし現実には, せん断クラックの進入角 $\theta$ を含め, 以後実験により更なる検証が必 要である.

表 3 壁土の最大圧縮強度から推測される壁土の必要引張強度

\begin{tabular}{|c|c|c|c|c|}
\hline $\begin{array}{l}\sigma_{\max } \\
\left(\mathrm{N} / \mathrm{mm}^{2}\right)\end{array}$ & $\begin{array}{l}\text { 隅角部によ } \\
\text { る } \mathrm{M}(\mathrm{Nm})\end{array}$ & $\begin{array}{l}\text { 貫による } \\
\mathrm{M}(\mathrm{Nm})\end{array}$ & $\begin{array}{l}\text { せん断 } \\
\text { 力 }(\mathrm{kN})\end{array}$ & $\begin{array}{c}\text { 必要引 } \\
\text { 張強度 }\end{array}$ \\
\hline 1.0 & $3.86 \mathrm{E}+04$ & $2.48 \mathrm{E}+03$ & 23.26 & 0.28 \\
\hline 0.8 & $3.09 \mathrm{E}+04$ & $1.99 \mathrm{E}+03$ & 18.60 & 0.22 \\
\hline 0.6 & $2.32 \mathrm{E}+04$ & $1.49 \mathrm{E}+03$ & 13.95 & 0.16 \\
\hline 0.4 & $1.55 \mathrm{E}+04$ & $9.94 \mathrm{E}+03$ & 9.30 & 0.10 \\
\hline
\end{tabular}

(壁長 $1820 \mathrm{~mm}$ ，壁高さ $2730 \mathrm{~mm}$ ，土壁厚 $70 \mathrm{~mm}$,

貫幅 $15 \mathrm{~mm}$ ，貫段数 3)

\section{4. 結語}

本報では, 数值解析による壁土強度の異なる土壁における耐力予測 手法の確立を目的として, 壁土の配合を変えた土壁を作成し, 実験・ 解析を行った。 その結果, 以下の知見が得られた.

a) 半間の土壁の骨格曲線に十分適用可能なことが判明した.

b)一間の土壁では, 土壁の壁土が剥離するまでは十分な精度を持っ て，その骨格曲線を予測した。

c)一間の土壁における壁土剥離時期およびその後の耐力を予測でき なかった。

d) 壁土剥離の要因を推測したものの, その現象の全てを説明できな かった.

従って, 今後は, 壁土が剥離する要因を, 材料特性, 亀裂の発生状 況を含めて検討する必要がある.

\section{謝辞}

本研究の一部は, 地域イノベーション創出総合支援事業 重点地 域研究開発推進プログラム 平成 21 年度「シーズ発掘試験」 A (発 掘型), 文部科学省科学研究費補助金・基盤研究(S) (課題番号 19106010, 研究代表者：鈴木祥之）により行われた. 記して謝意を示す.

\section{参考文献}

1）村上雅英, 景山誠, 鈴木有, 稲山正弘 : 静的水平加力実験に基づく土壁の 耐荷機構の解明一せん断破壊が先行しない土壁の力学挙動一, 日本建築学 会構造系論文集，No. 582, pp. 103-108，2004.8

2) 村上雅英, 景山誠, 岡本滋史, 鈴木有, 稲山正弘 : 要素試験による土壁の 水平力耐荷機構の検証一せん断破壊が先行しない土壁の力学挙動(続)一. 日本建築学会構造系論文集, No. 594, pp. 111-118, 2005.8

3）村上雅英, 景山誠, 岡本滋史, 鈴木有, 稲山正弘 : 水平力の耐荷機構に基 づく土壁の剛性と耐力の算定法に関寸る提案と検証, 日本建築学会構造系 論文集，No. 605，pp. 119-126，2006.7

4) 中尾方人, 一文字里紗, 山崎裕, 石橋庸子 : 土塗り壁のせん断抵抗機構お よびせん断耐力の評価法に関する実験的研究, 日本建築学会構造系論文集, No. 598, pp. 109-116, 2005.12

5）村上雅英ら：耐荷機構に基づく土壁の構造性能評価法の提案と検証（その 1-6）日本建築学会大会学術講演梗概集， C-1， pp. 405-416, 2004.

6）鈴木祥之, 中治弘行 : 木造住宅土塗り壁の実大実験による耐震性能の再検 討, 日本建築学会構造系論文集, No. 515, pp. 115-122, 1999.1

7）山田真澄, 鈴木祥之, 後藤正美, 清水秀丸: 単位木造フレームを用いた動 的・静的実験による木造軸組の耐震性能評価, 日本建築学会構造系論文集, No. 582 , pp. $95-102,2004.8$

8) 山田耕司: 土壁耐力の数值解析手法の開発, 日本建築学会技術報告集 第 23 号, pp. 161-164, 2006.

9）山田耕司, 清水秀丸, 中治弘行, 鈴木祥之: 土塗り小壁付き木造軸組耐力 特性評価への数值解析の適用, 日本建築学会構造系論文集 第 621 号, pp.81-87, 2007.11

10）鎌田輝男, 清水秀丸, 細入夏加, 中治弘行, 鈴木祥之, 後藤正美 : 土塗 り垂れ壁構面の耐震性能評価に関する研究-パラメータが耐震性能に及ぼ す影響, 第 12 回日本地震工学シンポジウム, pp. 778-781, 2006.

11）山田耕司, 中治弘行, 鈴木祥之 : 壁土の配合と強度に関する定性的傾向, 日本地震工学会・大会 -2009 梗概集, pp. 332-333, 2009

12）山田耕司, 中治弘行, 鈴木祥之: 壁土材料試験体の定温乾燥機による乾燥, 日本建築学会大会学術講演梗概集 (東北), B-1, pp. 459-460, 2009

13）岡本 滋史, 澤田 圭, 村上 雅英, 鈴木 有, 稲山 正弘：部分壁体試 験に基づく土壁のせん断力-変形角関係及び壁倍率の推定方法と検証，日 本建築学会構造系論文集 第 621 号, pp. 103-110, 2007. 11

（2010年 3 月 12 日原稿受理，2010年11月 9 日採用決定） 